\title{
A LA ENTRAÑABLE PRESENCIA DE Alberto Flores Galindo
}

"A las aladas almas de las rosas del almendro de nata te requiero, que tenemos que hablar de muchas cosas compañero del alma, compañero".

MIGUEL HERNANDEZ

ESTE NUMERO monográfico especial de Allpanchis aparece cuando se cumple, el 26 de marzo de 1991, un año del fallecimiento de quien fuera nuestro director entre 1978 y 1983, Alberto Flores Galindo. A su memoria $y$ en su homenaje, es que queremos dedicarle el trabajo que ahora presentamos.

En esta tribuna que contribuyó a crear, como tantas otras, queremos, por eso, recordarlo. Flores Galindo se incorporó como director de la revista en 1978. Asunción Marco lo propuso a los directores del Instituto de Pastoral Andina. Allpanchis tenía publicados diez números y había quedado sin director, Tito aceptó la propuesta pues le interesaba conocer la historia y la cultura de la región surandina, en la que ya había trabajado a propósito de su libro sobre Arequipa. Tomó a su cargo la revista y no pasó mucho tiempo antes que se señalaran protestas por su incorporación en tal cargo: la revista había cambiado de giro, dejando la antropología y la reflexión sobre la cultura religiosa. Pero en poco tiempo esos temas fueron tratados en Allpanchis, con profun- 


\section{Alberto Flores G/lindo}

didad, de manera polémica y con calidad. Aprendía constantemente y no dejaba escapar la oportunidad para convocar a nuevos colaboradores, renovar las perspectivas, abrir las posibilidades. Cuando dejó la dirección de la revista, en 1984, estuvo en Cusco varias veces, visitando los pueblos tupamaristas, dictando charlas, creando conocimiento. Conversaba con todos, preguntaba, visitaba el archivo, las personas que podian darle testimonio lo apreciaban por su afabilidad. No dudamos en afirmar que, no habiendo residido en el Cusco o en la región, Tito era una presencia constante entre nosotros, y Allpanchis fue el resultado de su actitud creadora.

Algunas páginas que él mismo escribiera en Allpanchis nos pueden servir para recordarlo entrañablemente. En 1984, Tito escribió una nota introductoria al último número que condujo de la revista. Tuvo la felicidad, que nosotros no podremos fatalmente tener para con él, de festejar entonces los sesenta años de su maestro, Ruggiero Romano. Tito fue también, y tan fácil y dócilmente, maestro, como escribía sobre Romano: "historiador prolífico y múltiple... prolongaba sobre el terreno esa unión estrecha entre historia $y$ vida... No es lo mismo profesor que maestro. Incluso los términos pueden terminar siendo contrapuestos, un maestro es la persona que sigue de cerca, paso a paso, el trabajo de su alumno. De sus alumnos sabe exigir trabajo. Gusta internarse por rutas poco trajinadas, ubicándose en las fronteras de la historia".

Tito había señalado antes esa apuesta vital, su mensaje de maestro $y$ amigo. Fue en su nota de homenaje a Basadre, en Allpanchis de 1980. Jorge Basadre - la voluntad de persistir la tituló, y escribió que don Jorge había persistido como historiador. Decía Tito entonces: "para Basadre, historia $y$ vida se confundian y se entremezclaban: ante todo fue un historiador, un hombre apasionado con su oficio, que nunca perdió el entusiasmo por la formulación de problemas, por la acuciosa lectura de los testimonios y por el ejercicio de recrear el pasado 
interpretándolo". Insistente en esa idea que planteara iêspecto a la relación entre la viúa y la historia, la pasión por el oficic ì por la vida, que en él se dejaba ver desde el movimiento desordenado de sus manos, en su caminar y en la sonrisa, pretendía siempre conocer vitalmente, no buscaba datos, vivía en la creación de su conocimiento. Por eso nunca estuvo solo y sus amigos y alumnos lo apreciaron tanto como lo quisieron. Por eso también más de uno le temía. Su opción por la vida lo convertía en observador tenaz, pero también en agudo crítico. Convocaba y también decantaba.

No ha terminado su labor en el mundo andino pues podremos más adelante recoger su semilla; dejó ideas, entusiasmos, alumnos, amigos, grupos. Ahora a todos nos hace falta, pero también deberemos aprender que es su presencia en nosotros su legado más grande, junto con su trabajo de investigación y difusión; nuevamente, historia $y$ vida se entremezclan.

Persistir cuando te echemos de menos. Crear, replantear, conversar, gozar, son los verbos con los que te tendremos presente. Aquí estarás siempre con nosotros amigo.

Basadre terminó su prólogo a las Bases Documentales de su Historia de la República con las palabras que escribió un poeta; hagámoslo como él, para pensar en otro maestro:

Que los que quieran escarben las materias aciagas; que levanten los fragmentos sin luz de la ceniza $y$ hablen en el idioma negativo. Yo tengo frente a mí sólo semillas, desarrollos radiantes $y$ esperanzas. 